\title{
Natural minerals mixture for enhancing concrete compressive strength
}

\author{
Abdoullah Namdar \\ Faculty of Civil Engineering \& Earth Resources, Universiti Malaysia Pahang, Malaysia \\ ab_namdar@yahoo.com
}

\begin{abstract}
The construction material quality is required to be improved in order to enhancing structure stability, optimizing construction cost and quality. The kaolin and bentonite have been mixed in equal quantity and treated by heat for 1 hour under $600{ }^{\circ} \mathrm{C}, 800{ }^{\circ} \mathrm{C}$ and $1000{ }^{\circ} \mathrm{C}$ to create new minerals under high temperature condition to introduce an acceptable concrete additive for achieving concrete compressive strength in early age. To study micro properties of additive-cement mixture, X-ray and FESEM experiments have been used. The results indicate that acceptable proportion of unheated kaolin-bentonite is improving the concrete compressive response. But if kaolin-bentonite mixture treated by heat under $800{ }^{\circ} \mathrm{C}$ and in quantity of $12 \%$ has been used in concrete mixed design, then the concrete compressive strength of 7 days shows the best result. The result is due to the development of new minerals under high temperature condition in mineral mixture and also kaolinbentonite additive change cement past crystal and lead to enhancement of nano structural cement bonding.
\end{abstract}

KEYwORDS. Concrete additive; Kaolin; Bentonite; Heat treatment; New minerals.

\section{INTRODUCTION}

7 he use of high-fast strength concrete has many applications, both technical and economical. Over last decade, the high strength concrete in short time was very important issue for researcher. The reconnaissance on economically and feasibility concrete additive is highly significant in construction industry.

A high strength concrete is introduced by using large volumes of low calcium as an additive and compressive strength of $80 \mathrm{MPa}$ was for 28 days [1]. The various chemical and supplementary cementitious materials are investigated on improvement concrete compressive strength [2-3]. And also fly ash, bottom ash and coarse aggregate mechanical properties and quality are evaluated for enhancement of concrete compressive strength [4-7]. The natural minerals are shown good results among other techniques. The investigation show natural minerals are improved concrete compressive strength and cement geopolymer [8-11]. From other view of point the investigation on materials macroscopic quality and minerals in concrete mix design is important topic for construction industry [12-13]. For example geopolymers can be synthesized from aluminosilicate powders including natural pozzolans [14-15]. The replacing cement by mineral additions resulted in lower early age strength and low cement quantity consumption [16]. The modern construction projects are trust to high strength concrete [17]. To optimize admixture cost and better improvement concrete characteristics many methods have been introduced [18-20]. The natural minerals mixture treatment by heat to develop new minerals based on kaolin-benonite interaction minerals in high temperature for produced new materials which can be useful as a concrete additive in concrete mixed design process have been investigated in order to improve concrete compressive strength in short term for minimizing construction time and cost. 


\section{METHODOLOGY}

$\mathrm{T}$ he natural minerals have ability in producing new material or modifying characteristics of materials. In this research work the kaolin and bentonite have been selected for improve concrete compressive strength. The kaolin and bentonite have been mixed in equal weight and subjected to the heat for 1 hour for $600{ }^{\circ} \mathrm{C}, 800{ }^{\circ} \mathrm{C}$ and 1000 ${ }^{\circ} \mathrm{C}$. The main propose for mixing kaolin and bentonite before submitting to heat is to analysis minerals of kaolin and bentonite interaction in high temperatures. The unheated and new produced materials have been mixed with concrete for $6 \%$ and $12 \%$ of cement weight (Tab. 1). The compressive strength of concrete for 7 days and 14 days has been tested. To study macro properties of additive-cement mixture X-ray experiment and FESEM have been used.

\section{RESULT AND DISCUSSION}

$\mathrm{I}$

n Figs. 1-3 the image of FESEM shows Nano particles of cement past without additive and, when 6\% and $12 \%$ additive have been used in concrete mixed design. In Fig. 1 the Nano particle have almost plane shape and in Fig. 2 the shape is convert to the lengthy shape and in Fig. 3 this process is increased, and subsequently resulted in improving concrete compressive strength. The additive creates new crystal structure in cement past. The result is indicated that $6 \%$ proportion of unheated kaolin-bentonite is improving concrete compressive. And if kaolin-bentonite mixture treated by heat under $800{ }^{\circ} \mathrm{C}$ and in quantity of $12 \%$ of cement weight has been used in concrete mixed design the concrete compressive strength of 7 days is resulted in improving concrete compressive strength in maximum level. It is due to develop new crystal morphology under high temperature condition in bentonite-kaolin-cement mixture and also considerably enhancement bonding of cement. If quantity of bentonite-kaolin mixture treated by heat increased in concrete mixed design resulted in better enhancement compressive strength, and it is not for unheated bentonite-kaolin mixture.

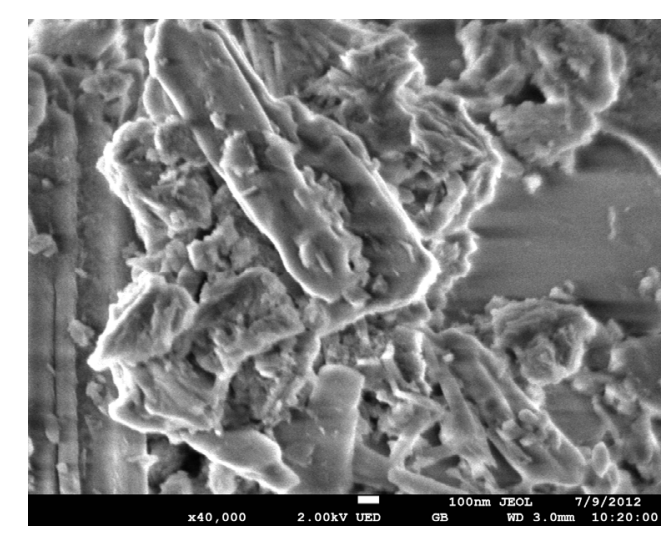

Figure 1: Image FESEM of cement.

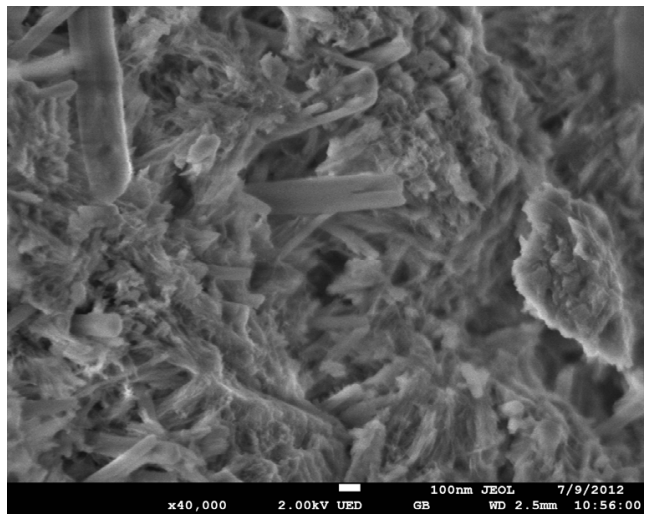

Figure 2: Image FESEM of cement mixed with $6 \%$ additive.

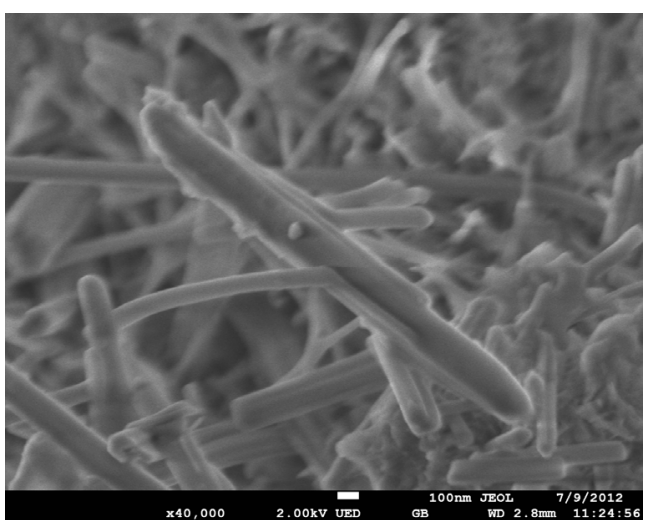

Figure 3: Image FESEM of cement mixed with $12 \%$ additive. 
The Fig. 4 is highlighted XRD pattern of cement, and cement- kaolin-bentonite mixture, the kaolin-bentonite was submitted to $800{ }^{\circ} \mathrm{C}$ heat for 1 hour. The XRD pattern shown that $\mathrm{Ca}(\mathrm{OD})$ is converted to $\mathrm{Ca}(\mathrm{OH})_{2}$ but no significant change in XRD pattern in increasing kaolin-bentonite mixture from $6 \%$ to $12 \%$ in concrete mixed design.

The Tab. 2 and Fig. 5 show the result of different mixed design for compressive strength of concrete. The result is indicated appropriate proportion of natural minerals mixture can improve concrete compressive strength without and treatment process.

\begin{tabular}{cccccc}
\hline S1 & $\begin{array}{c}\text { Con } \\
\text { type }\end{array}$ & $\begin{array}{c}\text { Unheated } \\
\text { additive }(\%)\end{array}$ & $\begin{array}{c}\text { Additive } \\
\text { produced } \\
\text { by } 600^{\circ} \mathrm{C} \\
(\%)\end{array}$ & $\begin{array}{c}\text { Additive } \\
\text { produced by } \\
800{ }^{\circ} \mathrm{C}(\%)\end{array}$ & $\begin{array}{c}\text { Additive } \\
\text { produced by } \\
1000{ }^{\circ} \mathrm{C}(\%)\end{array}$ \\
\hline 1 & 40 & - & - & - & - \\
2 & 40 & 6 & - & - & - \\
3 & 40 & 12 & - & - & - \\
4 & 40 & - & 6 & - & - \\
5 & 40 & - & 12 & - & - \\
6 & 40 & - & - & 6 & - \\
7 & 40 & - & - & 12 & 6 \\
8 & 40 & - & - & - & 12 \\
9 & 40 & - & - & - & \\
\hline
\end{tabular}

Table 1: Concrete-additive mixture ratio.

\begin{tabular}{|c|c|c|c|c|}
\hline $\mathrm{Sl} \mathrm{No}$ & Type of concrete & Additive (\%) & $\begin{array}{c}7 \text { days } \\
\text { Stress }\left(\mathrm{N} / \mathrm{mm}^{2}\right)\end{array}$ & $\begin{array}{c}14 \text { days } \\
\text { Stress }\left(\mathrm{N} / \mathrm{mm}^{2}\right)\end{array}$ \\
\hline 1 & Without additive & - & 25.77 & 30.48 \\
\hline 2 & Natural additive & 6 & 33.65 & 34.50 \\
\hline 3 & Natural additive & 12 & 21.87 & 28.44 \\
\hline 4 & $\begin{array}{l}\text { Additive produced under } \\
\qquad 600^{\circ} \mathrm{C} \text { heat }\end{array}$ & 6 & 18.70 & 33.07 \\
\hline 5 & $\begin{array}{l}\text { Additive produced under } \\
\qquad 600^{\circ} \mathrm{C} \text { heat }\end{array}$ & 12 & 25.14 & 40.19 \\
\hline 6 & $\begin{array}{l}\text { Additive produced under } \\
\qquad 800^{\circ} \mathrm{C} \text { heat }\end{array}$ & 6 & 30.95 & 35.15 \\
\hline 7 & $\begin{array}{l}\text { Additive produced under } \\
\qquad 800^{\circ} \mathrm{C} \text { heat }\end{array}$ & 12 & 40.32 & 42.39 \\
\hline 8 & $\begin{array}{l}\text { Additive produced under } \\
\qquad 1000^{\circ} \mathrm{C} \text { heat }\end{array}$ & 6 & 27.05 & 31.70 \\
\hline 9 & $\begin{array}{l}\text { Additive produced under } \\
\qquad 1000^{\circ} \mathrm{C} \text { heat }\end{array}$ & 12 & 31.97 & 33.44 \\
\hline
\end{tabular}

Table 2: Concrete compression strength. 


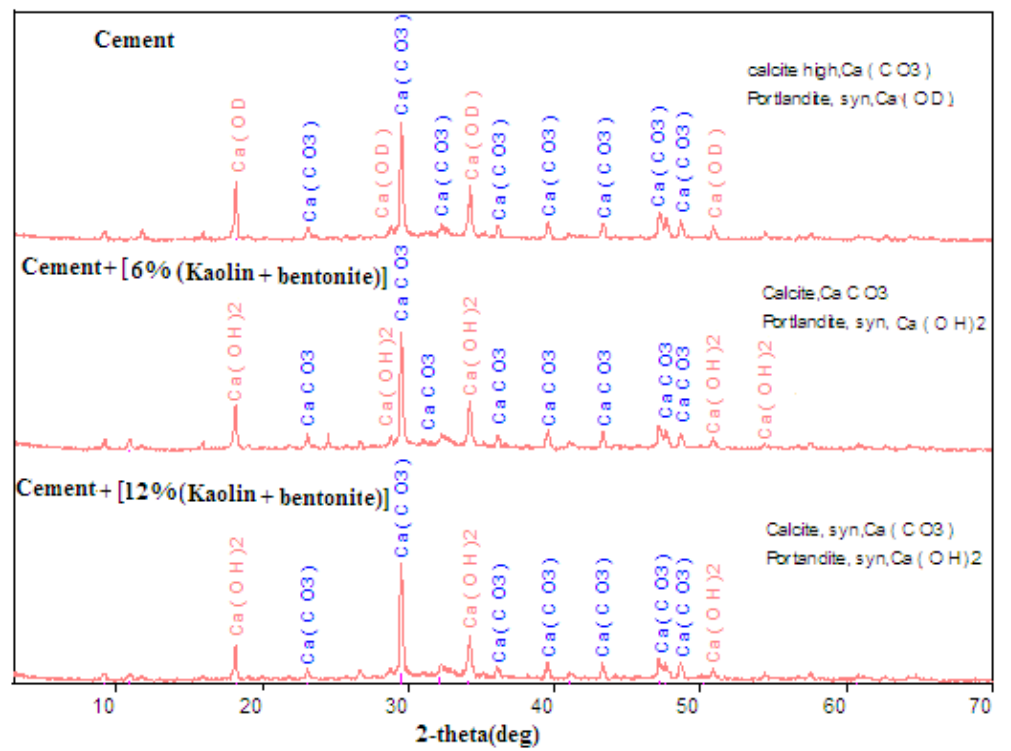

Figure 4: XRD pattern of cement, and cement-kaolin-bentonite mixture, the kaolin-bentonite was submitted to $800{ }^{\circ} \mathrm{C}$ heat for 1 hour.

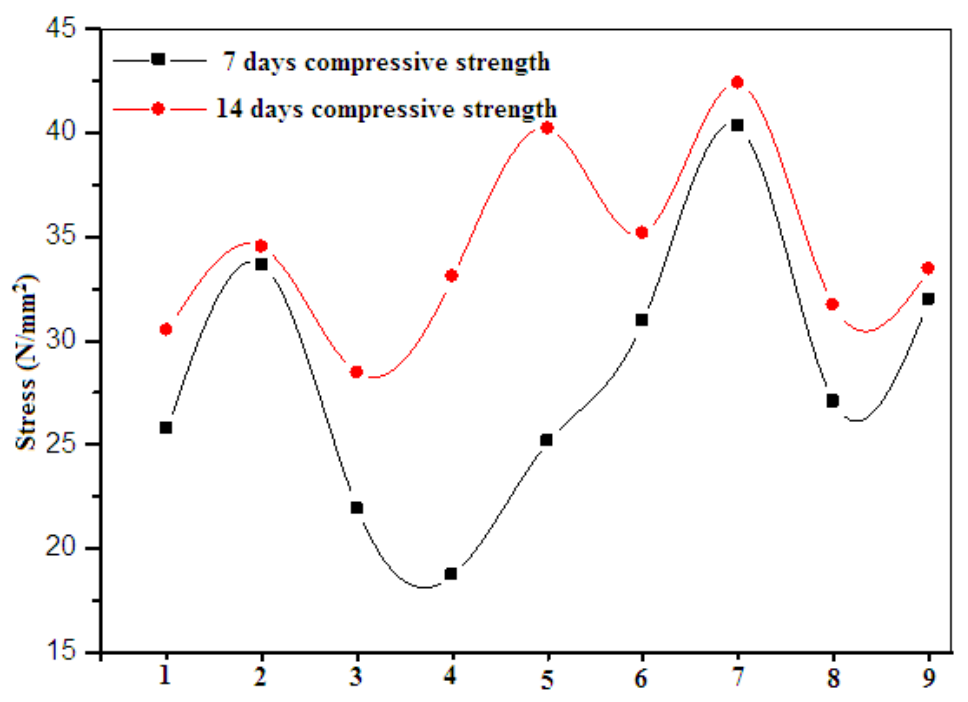

Figure 5: Concrete compressive strength.

\section{CONCLUSION}

The FESEM image indicated changing crystal structure of cement past is responsible for enhancing concrete compressive strength.

$\checkmark$ The proportion of additive before subjected to heat has different effect on concrete compressive strength compare to when additive is modified under high level of heat.

$\checkmark$ The quantity of $12 \%$ additive produced by $800{ }^{\circ} \mathrm{C}$ heat has shown best result in improving concrete compressive strength.

$\checkmark$ The amount of $6 \%$ additive not subjected to the heat has shown acceptable result in improving concrete compressive strength.

$\checkmark$ Increasing bentonite-kaolin mixture which was treated by heat in concrete mixed design resulted in better enhancement compressive strength. 


\section{REFERENCES}

[1] C.S. Poon, L. Lam, Y.L. Wong, Cement and Concrete Research, 30 (2000) 447.

[2] U. S. Yilmaz, H. Turken, Civil Engineering, 55(2) (2011) 107.

[3] M.A. Megat Johari, J.J. Brooks, S. Kabir, P. Rivard, Construction and Building Materials,; 25, (2011) 2639.

[4] H. Beshr, A.A. Almusallam, M. Maslehuddin, Construction and building materials, 17 (2003) 97.

[5] A. Kilic, C. D. Atiş, A. Teymen, O. Karahan, F. Özcan, C. Bilim, M. Özdemir, Cement \& Concrete Composites, 30 (2008) 290.

[6] H.K. Kim, H.K. Lee, Construction and Building Materials, 25 (2011) 1115.

[7] U. Atici, Expert Systems with applications, 38 (2011) 9609.

[8] A. Behnood, H. Ziari, Cement \& Concrete Composites, 30 (2008) 106.

[9] H. Yazici, Building and Environment, 42 (2007) 2083.

[10] D. Bondar, Alkali activation of Iranian Natural pozzolans for producing geopolymer cement and concrete. Ph.D. Thesis, University of Sheffield, UK (2009).

[11] H. Xu, J.S.J. Van Deventer, Int J Mineral Process, 59 (2000) 247.

[12] P. Folino, G. Etse, Int. J. of Solids and Structures, 49 (2012) 701.

[13] Dali Bondar, C.J. Lynsdale, N.B. Milestone, N. Hassani, A.A. Ramezanianpour, Construction and Building Materials, 25 (2011) 2906.

[14] J. Davidovits, J. Therm. Anal., 37 (1991) 1663.

[15] J. Davidovits, J. Mater. Educ., 16 (1994) 91.

[16] M. I. A. Khokhar, E. Roziere, P. Turcry, F. Grondin, A. Loukili, Cement \& Concrete Composites, 32 (2010) 377.

[17] K. Kovler, O. Jensen, Concr Int, 27(9) (2005) 39.

[18] S. Shah, J. Weiss, W. Yang, Concr. Int., 20(4) (1998) 51.

[19] D. Bentz, Cementitious barriers partnership, (2009) CBP-TR-2009-002-C3.

[20] ACI-231. Report on early-age cracking: causes, measurement and mitigation. Farmington Hills (MI): American Concrete Institute; (2010). 